\title{
NYMPHAEETUM ALBAE VOLLMAR 1947 EM. OBERD. IN OBERD. ET AL. 1967, A PLANT ASSOCIATION NEW TO POLAND
}

\author{
KRZYSZTOF SPAŁEK \\ Laboratory of Geobotany and Plant Conservation \\ Department of Biosystematics, University of Opole \\ Oleska 22, 45-052 Opole, Poland \\ e-mail: kspalek@uni.opole.pl
}

(Received: June 2, 2006. Accepted: November 15, 2006)

\begin{abstract}
The paper presents a water plant community new to Poland - Nymphaeetum albae Vollmar 1947 em. Oberd. in Oberd. et al. 1967, belonging to the Potametea class. It was discovered in fishponds in Pokój near Namysłów, Lasowice Małe near Kluczbork and small ponds in Staniszcze Małe near Opole in Silesia (SW Poland). Floristic composition and ecological requirements of this association are presented in the paper. Nymphaeetum albae is considered to be a rare and endangered plant community in Europe.
\end{abstract}

KEY WORDS: Nymphaeetum albae, Potametea class, distribution, phytosociology, Poland, endangered association.

\section{INTRODUCTION}

Nymphaeetum albae Vollmar 1947 em. Oberd. in Oberd. et al. 1967 was first recognized at peatbogs in Murnau (Bavaria, Germany) in poor, mesotrophic or oligotrophic, cold mountain ponds (Vollmar 1947). Subsequently, it has been found in other regions of Germany (Jeschke 1959; Müller and Görs 1960; Hilbig 1971; Pott 1980, 1983; Wittig 1980; Runge 1990), in Great Britain (Spence 1964; Rodwell 2000) and in Austria (Amann 1985; Grabherr and Polatschek 1986; Wittmann and Strobl 1990; Schratt 1993). This community occurs in shallow $(30-200 \mathrm{~cm})$, oligotrophic, dystrophic or mesotrophic acid ( $\mathrm{pH} 4.7-6.5)$ ponds in peatbogs, ponds formed after peat extraction, muddy fishponds and less frequently in oligotrophic ponds with alkaline water, with a layer of lime gyttja on the bottom (Vollmar 1947; Jeschke 1959; Müller and Görs 1960; Spence 1964; Hilbig 1971; Oberdorfer 1977; Pott 1980, 1983, 1995; Wittig 1980; Amann 1985; Grabherr and Polatschek 1986; Runge 1990; Wittmann and Strobl 1990; Palmer 1992; Schratt 1993; Schubert et al. 1995; Rodwell 2000). The characteristic and dominant species of Nymphaeetum albae is Nymphaea alba var. minor. This variety has smaller leaves and flowers and occurs in mesotrophic and oligotrophic waters poor in nutrients (Sauer 1937; Krausch 1964; Konczak 1968; Rothmaler 1986; Dostál 1989, Oberdorfer 1994). Differential species for this association are Juncus bulbosus, Sparganium minimum, Potamogeton gramineus and Potamogeton natans (Pott 1995). Nymphaeetum albae is distinctly internally differentiated. Until pre- sent, five of its subassociations have been distinguished: Nymphaeetum albae typicum, Nymphaeetum albae myriophylletosum spicati, Nymphaeetum albae sparganietosum minimae (Müller and Görs 1960; Oberdorfer 1977; Pott 1980), Nymphaeetum albae utricularietosum australis (Müller and Görs 1960) and Nymphaeetum albae juncetosum bulbosi (Pott 1980; Rodwell 2000). This association is considered to be poor in species and consists of about 2-15 taxa on average (Müller and Görs 1960; Pott 1980). This aqutic plant community is recognized as endangered at both regional and Central European scale (Wittmann and Strobl 1990; Pott 1995; Schubert et al. 1995; Rennwald 2000).

The presence of Nymphaeetum albae phytocoenosis have not yet been recorded in Poland since no studies on distribution of Nymphaea alba var. minor have been performed until today.

This paper describes the Nymphaeetum albae community. The phytosociological table is given and floristic composition and ecological requirements of this community are discussed.

\section{METHODS}

The fieldwork was conducted during vegetation seasons 1998 and 2006. Nymphaeetum albae community was studied following the Zurich-Montpellier School of Phytosociology (Braun-Blanquet 1964). Phytosociological nomenclature and syntaxonomical attachment are based on 
Oberdorfer (1994), Pott (1995) and Matuszkiewicz (2005). Vascular plant species names are given according to Mirek et al. (2002), and bryophytes to Frahm and Frey (1992). The subassociations were assigned on the basis of following works Müller and Görs (1960), Oberdorfer (1977) and Pott (1980). Hydrogen ion concentration was measured with Elmetron pH microcomputer CP-315.

\section{RESULTS}

During geobotanical investigations carried out in southwestern Poland three localities of Nymphaeetum albae were discovered. These localities are situated in fishponds in Pokój near Namysłów, not cultivated fishpond in Lasowice Małe near Kluczbork and small forest ponds in Staniszcze Małe near Opole in Silesia, which are former gravel pits (Fig. 1). The total coverage of the community in 2006 was up to 1.0 ha in Pokój, 0.5 ha in Lasowice Małe and 1.5 ha near Staniszcze Małe. Nymphaeetum albae develops in water of the depth $20-160 \mathrm{~cm}$ and $\mathrm{pH} 6.3$ to 6.7 (Table 1). It occurs in very clear waters, a slightly increased ammonium content in the waters in Staniszcze Małe is supposed to be an effect of the putrefaction processes of the organic substances laying on the reservoir bottom (Table 1). In this community Nymphaea alba var. minor predominates (Table 2).

The community Nymphaeetum albae is diversified into four forms at these localities. In deeper and less acid fishponds there form patches of the typical subassociation Nymphaeetum albae typicum. More shallow and acid wa-

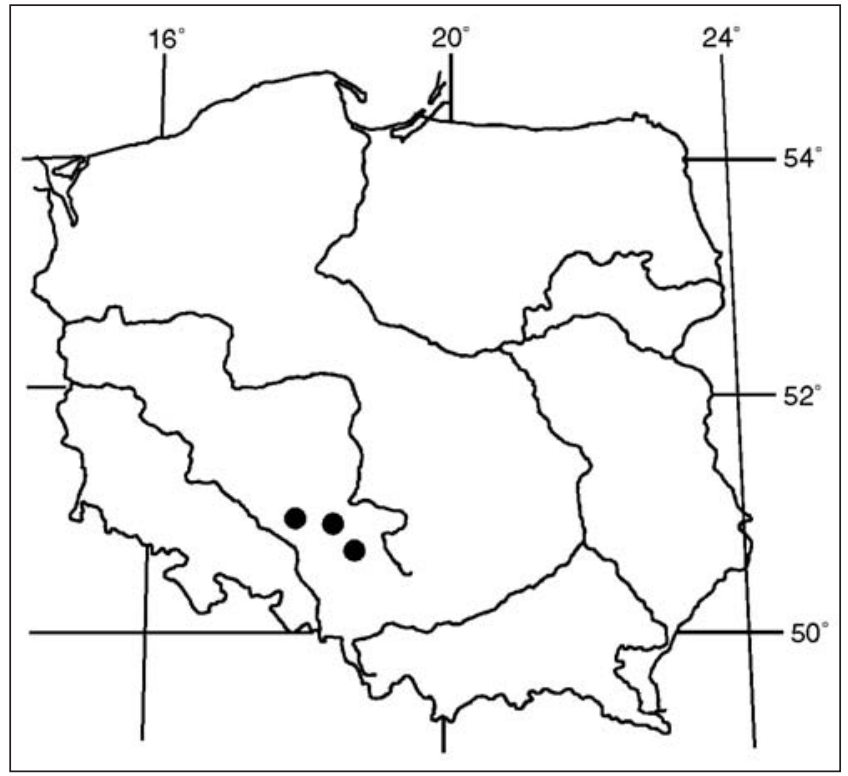

Fig. 1. Localities of Nymphaeetum albae in Poland. ters are habitats of patches of the following subassociations: Nymphaeetum albae sparganietosum minimae, Nymphaeetum albae juncetosum bulbosi and Nymphaeetum albae utricularietosum australis.

The typical subassociation occurs at lower montane locations and on lowlands in various types of water ponds with muddy or peaty bottoms, in waters poor in nutrients of the depth up to $200 \mathrm{~cm}$ (Müller and Görs 1960; Oberdorfer 1977; Pott 1980). In Poland patches of this subassociation were found in fishponds near Pokój. It occurs in deeper waters - between 100 and $160 \mathrm{~cm}$, but less acid - of $\mathrm{pH}$ 6.7, on muddy bottom. In its patches Nymphaea alba var. minor, Potamogeton natans and Ceratophyllum demersum predominate (Table 2 , relevés 1,2 ). In total, in its phytocenoses 7 plant species were recorded. In this subassociation the bryophyte layer was not formed.

Nymphaeetum albae sparganietosum minimae occurs in acidulous ponds on peat silt moderately poor in mineral components or in ditches crossing peatbogs and peat extraction pits. It occurs in waters of the depth from 30 to $150 \mathrm{~cm}$. It is different from the typical subassociation due to the occurrence of Sparganium minimum, Utricularia minor and Utricularia intermedia (Müller and Görs 1960; Oberdorfer 1977; Pott 1980). In Poland phytocenoses of this subassociation were found in small forest ponds in Staniszcze Małe near Opole and in not cultivated fishpond in Lasowice Małe near Kluczbork. Nymphaeetum albae sparganietosum minimae occurs in shallow waters of the depth $20-120 \mathrm{~cm}$, on peat substratum, in more acid waters of $\mathrm{pH}$ 6.3. In its patches there predominate Nymphaea alba var. minor, Sparganium minimum and Utricularia minor (Table 2 , relevés 3-6). In total, in its phytocenoses 8 plant species were noted. In its weakly developed bryophyte layer Sphagnum fallax occurs.

The subassociation Nymphaeetum albae juncetosum bulbosi occurs in shallow waters on the peatbog surface. Most often they are small boggy floods near ponds. Differential species for this association are: Juncus bulbosus, Sphagnum subsecundum, Sphagnum cusoidatum f. plumosum, Eleogiton fluitans and Polygonum amphibium f. natans (Pott 1980). In Poland patches of this subassociation were found in not cultivated fishponds in Lasowice Małe. This subassociation occurs in shallow waters of $\mathrm{pH} 6.5,20-50$ $\mathrm{cm}$ deep, on peat substratum. In its patches Nymphaea alba var. minor and Juncus bulbosus predominate (Table 2, relevés 7,8$)$. In total, in its phytocenoses 9 plant species were recorded. In the moderately formed bryophyte layer there occur Sphagnum fallax and in some places Sphagnum denticulatum.

Nymphaeetum albae utricularietosum australis grows in ponds of different type, on muddy bottom, in ponds among peatbogs, ponds formed in peat extraction pits and in peaty

TABLE 1 . The physico-chemical characteristics of water.

\begin{tabular}{|c|c|c|c|c|c|c|c|c|c|}
\hline Locality & $\begin{array}{c}\mathrm{Cl} \\
{[\mathrm{mg} / \mathrm{l}]}\end{array}$ & $\begin{array}{c}\text { Electrolytic } \\
\text { conductivity } \\
{\left[\mu \mathrm{S} / \mathrm{cm}^{2}\right]}\end{array}$ & $\begin{array}{c}\mathrm{pH} \\
\mathrm{H}_{2} \mathrm{O}\end{array}$ & $\begin{array}{c}\mathrm{BOD}_{5} \\
{\left[\mathrm{mgO}_{2} / \mathrm{l}\right]}\end{array}$ & $\begin{array}{c}\mathrm{O}_{2} \\
\text { Dissolved } \\
\text { oxygen } \\
{[\mathrm{mg} / \mathrm{l}]}\end{array}$ & $\begin{array}{c}\mathrm{PO}_{4} \\
\text { Phosphates } \\
{[\mathrm{mg} / \mathrm{l}]}\end{array}$ & $\begin{array}{c}\text { Nitrate } \\
\text { nitrogen } \\
{[\mathrm{mg} / \mathrm{l}]}\end{array}$ & $\begin{array}{c}\text { Ammonium } \\
\text { nitrogen } \\
{[\mathrm{mg} / \mathrm{l}]}\end{array}$ & $\begin{array}{c}\text { Nitrite } \\
\text { nitrogen } \\
{[\mathrm{mg} / \mathrm{l}]}\end{array}$ \\
\hline Lasowice Małe & 9.27 & 92.60 & 6.5 & 0.90 & 4.45 & 0.12 & 0.44 & 1.37 & 0.014 \\
\hline Pokój & 8.12 & 89.80 & 6.7 & 0.91 & 4.37 & 0.11 & 0.37 & 0.55 & 0.016 \\
\hline Staniszcze Małe & 10.44 & 96.90 & 6.3 & 2.03 & 5.28 & 0.12 & 0.48 & 2.37 & 0.013 \\
\hline
\end{tabular}


TABLE 2. Nymphaeetum albae Vollmar 1947 em. Oberd. in Oberd. et al. 1967

\begin{tabular}{|c|c|c|c|c|c|c|c|c|c|c|c|}
\hline Relevé number & 1 & 2 & 3 & 4 & 5 & 6 & 7 & 8 & 9 & 10 & $\mathrm{C}$ \\
\hline Date: year & 1998 & 2000 & 2002 & 2006 & 2006 & 1998 & 2001 & 2001 & 2001 & 2001 & \\
\hline month & 07 & 07 & 07 & 07 & 07 & 07 & 08 & 08 & 08 & 08 & \\
\hline day & 21 & 21 & 12 & 17 & 03 & 29 & 09 & 09 & 09 & 09 & \\
\hline Locality & $\mathrm{P}$ & $\mathrm{P}$ & SM & SM & SM & LM & LM & LM & LM & LM & \\
\hline Cover of herb layer [\%] & 70 & 65 & 65 & 60 & 55 & 50 & 50 & 45 & 45 & 45 & \\
\hline Cover of moss layer [\%] & - & - & 5 & 5 & 5 & + & + & 10 & 5 & 10 & \\
\hline Area of relevé $\left[\mathrm{m}^{2}\right]$ & 80 & 100 & 50 & 50 & 50 & 50 & 80 & 50 & 30 & 40 & \\
\hline Number of species in relevé & 7 & 5 & 4 & 5 & 6 & 7 & 4 & 9 & 5 & 8 & \\
\hline
\end{tabular}

Ch., D.* Nymphaeetum albae

Nymphaea alba var. minor

Potamogeton natans*

$\begin{array}{lllllllllll}4 & 4 & 3 & 3 & 3 & 3 & 3 & 3 & 3 & 3 \\ 2 & 1 & + & + & + & + & 1 & + & + & .\end{array}$

D. Nymphaeetum albae sparganietosum minimae

Sparganium minimum

Utricularia minor

D. Nymphaeetum albae juncetosum bulbosi

Juncus bulbosus

D. Nymphaeetum albae utricularietosum australis

Utricularia australis

Ch. Potametea

Ceratophyllum demersum

Elodea canadensis

Ch. Phragmitetea

Carex rostrata

Phragmites australis

Equisetum fluviatile

Oenanthe aquatica

\begin{tabular}{|c|c|c|c|c|c|c|c|c|c|c|}
\hline . & . & 2 & 2 & 2 & 1 & . & . & . & . & II \\
\hline . & . & . & . & . & 1 & . & + & . & . & I \\
\hline . & . & . & . & . & . & 2 & 2 & . & + & I \\
\hline . & $\cdot$ & . & $\cdot$ & . & . & . & . & 1 & 2 & I \\
\hline 1 & 2 & . & . & . & . & . & . & . & . & I \\
\hline+ & + & . & . & . & . & . & . & . & . & I \\
\hline . & . & . & . & + & + & . & + & + & . & II \\
\hline+ & $\cdot$ & $\cdot$ & $\cdot$ & . & $\cdot$ & $\cdot$ & + & . & + & II \\
\hline . & . & . & + & 1 & . & . & . & . & . & I \\
\hline . & $\cdot$ & $\cdot$ & . & . & . & . & + & . & 1 & I \\
\hline+ & $\cdot$ & . & . & . & + & . & . & . & + & II \\
\hline+ & + & . & . & $\cdot$ & . & . & . & . & . & $\mathrm{I}$ \\
\hline . & . & 1 & 1 & 1 & + & + & 2 & 1 & 2 & IV \\
\hline$\cdot$ & $\cdot$ & $\cdot$ & . & . & . & . & + & . & + & I \\
\hline
\end{tabular}

Ch. Lemnetea minoris

Lemna minor

Utricularia vulgaris

Accompanying species

Sphagnum fallax

Sphagnum denticulatum

d

d

Explanation: P - Pokój; SM - Staniszcze Małe; LM - Lasowice Małe; Ch. - characteristic species; D. - differential species; C - constancy; d - moss taxa

ditches. This subassociation occurs in mesotrophic and acid waters of pH 5.5-6.5 (Müller and Görs 1960). In Poland patches of this subassociation were found in an unused fishpond in Lasowice Małe. This subassociation occurs in shallow waters of the depth $20-80 \mathrm{~cm}$, on peat substratum, in waters of $\mathrm{pH}$ 6.5. In its patches dominants are Nymphaea alba var. minor and Utricularia australis (Table 2, relevés 9, 10). In total, in its phytocenoses 9 species of plant were recorded. In its intermediately formed bryophyte layer there occur Sphagnum fallax and in some places Sphagnum denticulatum.

Nymphaeetum albae usually built a micro-mosaic complex with associations from classes: Lemnetea minoris, e.g. Utricularietum australis (Spałek 2006), Potametea, e.g. Potametum natantis, Utricularietea intermedio-minoris, e.g. Sparganietum minimi and Littorelletea uniflorae, e.g. Ranunculo-Juncetum bulbosi. The average species number in the relevé was 6.

In the processes of natural succession phytocenoses of Nymphaeetum albae most often undergo transformation into Scirpetum lacustris, Typhetum latifoliae, Caricetum rostratae, Equisetetum fluviatilis and other rush associations (Rodwell 2000). On the newly found localities in Poland phytocoenoses of Nymphaeetum albae occur in a close contact with Caricetum rostratae, Equisetetum fluviatilis and Phragmitetum australis. Naturally, in the case of intensive fish farming in fishponds, the rush communities could disappear completely.

Localities of Nymphaeetum albae in Poland should be covered with species protection. One of them - fishponds in Pokój, is located within the Stobrawski Landscape Park. It is also planned to cover the pond in Laskowice Małe with legal protection as a nature reserve. At present it is designated as an area of ecological use in the local nature conservation strategy of Kluczbork municipality. Forest ponds in Staniszcze Małe are also covered with legal protection as areas of ecological use.

During the fieldwork, basic threats to plant communities of the ponds were identified. The most harmful seems to be restoration of the production area of fishponds in Pokój as a consequence of the program of fish culture intensification. In its result, deteriorating use of ponds is implemented, including regular mowing of the water zone and frequent deepening of ponds. The key factor allowing Nymphaeetum albae to develop is temporary drying out of the ponds. If the fish farm management caused permanent filling 
of the pond basin with water, the studied association would probably be endangered.

The complete phytosociological and habitat characteristic as well as the present distribution of Nymphaeetum albae in Poland should be the subject of further botanical investigations, as this association is probably more widespread.

\section{SYSTEMATICAL POSITION OF THE COMMUNITY}

Class: Potametea R. Tx. et Prsg. 1942

Order: Potametalia Koch 1926

Alliance: Nymphaeion Oberd. 1957

Association: Nymphaeetum albae Vollmar $1947 \mathrm{em}$. Oberd. in Oberd. et al. 1967

\section{ACKNOWLEDGEMENTS}

I wish to thank Prof. R. Pott, Institut für Geobotanik, Hannover, Prof. S. Kłosowski, Prof. H. Tomaszewicz, Warsaw University, Prof. J. Szmeja, Gdańsk University, for cooperation and Dr A. Stebel, Medical University of Silesia, Katowice, for determination of moss taxa.

\section{LITERATURE CITED}

AMANN M. 1985. Verbreitung geschützer Arten im Vorarlberger Rheintal zwischen Bodensee und Kummenberg (mit Ausnahme des Rheindeltas). (unpublished work), Univ. Innsbruck.

BRAUN-BLANQUET J. 1964. Pflanzensoziologie, Grundzüge der Vegetationskunde. Dritte Auflage. Springer Verlag, Wien-New York.

DOSTÁL J. 1989. Nová kvétena ČSSR. 1. Academia, Praha. (in Czech)

FRAHM J.-P., FREY W. 1992. Moosflora. Ed. 3. E. Ulmer, Stuttgart.

GRABHERR G., POLATSCHEK A. 1986. Lebensräume und Flora Vorarlbergs. Vorarlberger Verlagsanstalt, Dornbirn.

HILBIG W. 1971. Übersicht über die Pflanzengesellschaften des südlichen Teiles der DDR. 1. Die Wasserpflanzengesellschaften. Hercynia 8 (1): 4-33.

JESCHKE L. 1959. Pflanzengesellschaften einiger Seen bei Feldenberg in Mecklenburg. Feddes Repert. Beih. 138: 161-214.

KONCZAK P. 1968. Die Wasser- und Sumpfpflanzengesellschaften der Havelseen um Potsdam. Limnologica 6: 147-201.

KRAUSCH H.D. 1964. Die Pflanzengesellschaften des StechlinSee-Gebietes. I. Die Gesellschaften des offenen Wassers. Limnologica 2: 145-203.

MATUSZKIEWICZ W. 2005. Przewodnik do oznaczania zbiorowiska roślinnych Polski. Wydawnictwo Naukowe PWN, Warszawa (in Polish).

MIREK Z., PIĘKOŚ-MIRKOWA H., ZAJĄC A., ZAJĄC M. 2002. Flowering plants and pteridophytes of Poland - a chec- klist. In: Mirek Z. (ed.). Biodiversity of Poland 1, W. Szafer Institute of Botany, Polish Academy of Sciences, Kraków, p. 442.

MÜLLER T., GÖRS S. 1960. Pflanzengesellschaften stehender Gewässer in Baden-Württemberg. Beitr. Z. Naturk. Forschung i. Südwestdeutschland 19 (1): 60-100.

OBERDORFER E. (ed.) 1977. Süddeutsche Pflanzengesellschaften. Teil I. G. Fischer Verlag, Stuttgart-New York.

OBERDORFER E. 1994. Pflanzensoziologische Exkursionsflora. 7 Aufl. Verl. Eugen Ulmer, Stuttgart.

PALMER M. 1992. A botanical classification of standing water in Great Britain. 2nd edition. Joint Native Conservation Committe, Peterborough.

POTT R. 1980. Die Wasser- und Sumpfvegetation eutropher Gewässer in der Westfälischen Bucht - Pflanzensoziologische und hydrochemische Untersuchungen. Abh. Westf. Mus. f. Naturk. 42 (2): 1-156.

POTT R. 1983. Die Vegetationsabfolgen unterschiedlicher Gewässertypen Nordwestdeutschlands und ihre Abhängigkeit vom Nährstoffgehalt des Wassers. Phytocoenologia 11 (3): 407-430.

POTT R. 1995. Die Pflanzengesellschaften Deutschlands. 2 Aufl. Verl. E. Ulmer, Stuttgart.

RENNWALD E. (ed.) 2000. Rote Liste der Pflanzengesellschaften Deutschlands mit Anmerkungen zur Gefährdung. In: Rennwald E. (ed.). Verzeichnis und Rote Liste der Phlanzengesellschaften Deutschlands. Schr.-R.f. Vegetationskunde 35: 393-592.

RODWELL J.S. (ed.) 2000. British Plant Communities. Vol. 4. Aquatic communities, swamps and tall-herb fens. Cambridge University Press.

ROTHMALER W. 1986. Exkursionsflora. Band 4. Kritischer Band. 6 Aufl. Volk und Wissen, Berlin.

RUNGE F. 1990. Die Pflanzengesellschaften Mitteleuropas. Aschendorff, Münster.

SAUER F. 1937. Die Makrophytenvegetation ostholsteinischer Seen un Teiche. Arch. Hydrobiol., Suppl. 6: 431-592.

SCHRATT L. 1993. Potametea. In: Grabherr G., Mucina L. (eds). Die Pflanzengesellschaften Österreichs. Teil II. Natürliche waldfreie Vegetation. G. Fischer Verlag, Jena-Stuttgart-New York, pp. 53-78.

SCHUBERT R., HILBIG W., KLOTZ S. 1995. Bestimmungsbuch der Pflanzengesellschaften Mittel- und Nordostdetschlands. G. Fischer Verlag, Jena-Stuttgart.

SPAŁEK K. 2006. Utricularietum australis Th. Müller et Görs 1960 in Poland. Acta Soc. Bot. Pol. 75 (3): 253-256.

SPENCE D.H.N. 1964. The macrophytic vegetation of freshwater lochs, swamps and associated fens. In: Burnett J.H. (ed.). The Vegetation of Scotland. Oliver \& Boyd, Edinburgh, pp. 306-425.

VOLLMAR F. 1947. Die Pflanzengesellschaften des Murnauer Moores. Teil I. Ber. Bayer. Bot. Ges. 27: 13-97.

WITTMANN H., STROBL W. 1990. Gefährdete Biotoptypen und Pflanzengesellschaften in Salzburg - Ein erster Überblick. Amt der Salzburger Landesregierung, Salzburg.

WITTIG R. 1980. Die geschützen Moore und oligotrophen Gewässer der Westfälischen Bucht. Landesanstalt für Ökologie, Landschaftsentwicklung Forstplanung NRW, Schriftenreihe LÖLF 5: 1-228. 